\title{
A Case Report of Hyponatremia Associated with Maprotiline Treatment
}

\author{
Žana B. Stanković ${ }^{1}$, Zorana Z. Pavlović1,3, Milica J. Jovičicić, \\ Miloš P. Žarkovićc ${ }^{2,3}$ \\ ${ }^{1}$ Clinic for Psychiatry, Clinical Centre of Serbia, Belgrade, Serbia \\ ${ }^{2}$ Institute for Endocrinology, Diabetes and Diseases of metabolism, Clinical Centre of Serbia, \\ Belgrade, Serbia \\ ${ }^{3}$ School of Medicine, University in Belgrade, Belgrade, Serbia
}

\section{SUMMARY}

Background: Maprotiline is a tricyclic antidepressant (sometimes classified as a tetracyclic antidepressant), which is predominantly a norepinephrine/noradrenaline reuptake inhibitor, commonly prescribed for depression.

Aim: To present a female patient with depressive episode and occurrence of hyponatremia during the maprotiline treatment.

Case Report: A 62-year-old female was diagnosed with depressive episode four years ago. She was treated ambulatory with maprotiline $50 \mathrm{mg} /$ day and bromazepam $6 \mathrm{mg} /$ day, from local psychiatrist. The patients also used enalapril $2 \times 10 \mathrm{mg} /$ day, metoprolol $2 \times 50 \mathrm{mg} /$ day, nifedipine $5 \mathrm{mg} /$ day and simvastatin $20 \mathrm{mg} /$ day for treating hypertension and dyslipidemia. After about 12 months of maprotiline use she was hospitalized at the Endocrinology unit of a local hospital due to appearance of confusion, unstable walking, cramps, as well as an increase in blood pressure. Then diagnosed hyponatremia (serum sodium level-112 $\mathrm{mmol} / \mathrm{L}$ ), corrected $(137 \mathrm{mmol} / \mathrm{L})$ by using parenteral therapy. The patient continued to use maprotiline without consultation with her psychiatrist. After one year, the patient was hospitalized at the Endocrinology unit of tertiary level due to detailed re-examination because of recurrent hyponatramia (117 $\mathrm{mmol} / \mathrm{L})$, corrected $(136 \mathrm{mmol} / \mathrm{L})$ by ambulatory use of parenteral therapy at a local hospital. Water test load was used and the Syndrome of inappropriate antidiuretic hormone secretion was diagnosed. Insulin Tolerance Test showed preserved the integrity of the hypothalamic-pituitary-adrenal axis. Antidepressant mirtazapine (15 mg/ day) was introduced due to recurrence of depression. Gradual reduction of depressive symptoms was observed to mirtazapine. Antihypertensive therapy, restriction of fluid intake and dietary regimen were still applied. Serum sodium concentrations were in the normal ranges over the past 18 months.

Conclusion: Serum sodium level should be measured before and during the therapy with any class of antidepressants, especially in those patients with increased risk of the hyponatremia occurrence.

Keywords: antidepressants, side effects, hyponatremia, maprotiline, mirtazapine 


\section{INTRODUCTION}

Hyponatremia is an electrolyte abnormality which is clinically defined as serum sodium concentration of $<135 \mathrm{mEq} / \mathrm{L}$. This electrolyte disorder may be complication in the following diseases: heart failure, cirrhosis, adrenocortical insufficiency, diabetes mellitus or hyperglycemia, persistent diarrhea and/or vomiting, renal disorders, hypothyroidism, lower body weight, chronic obstructive pulmonary disease (COPD) and acquired immune deficiency syndrome (AIDS) [1].

Hyponatremia may occur as a side effect of a large number of different drugs, including nearly all psychotropics. Psychotropic drugs may cause hyponatremia by increasing hypothalamic production of antidiuretic hormone (ADH) [antidepressants (ADs) (Tricyclic ADs, Selective serotonin reuptake inhibitors (SSRIs), Monoamine oxidase inhibitors (MAOIs), antipsychotics (phenotiazines, butyrophenones), antiepileptic drugs (oxcarbazepine, sodium valproate)], potentiating of $\mathrm{ADH}$ effect (antiepileptic drug lamotrigine), resetting osmostat [ADs (Serotonergic and Noradrenergic Reuptake Inhibitors (SNRIs) (venlafaxine, duloxetine), Dopamine Reuptake Inhibitors (DRIs) (bupropion)] or through all of the above mentioned mechanisms (antiepileptic drug carbamazepine), although the exact mechanisms remain unclear.

ADs are most strongly associated with hyponatremia from all psychotropics. According to the reference literature, the risk of hyponatremia is considerably greater with SSRIs and SNRIs in relation to other classes of ADs $[1,2,3]$.

Non-psychotropic drugs that can induce hyponatremia are thiazides diuretics, angiotensin-converting enzyme (ACE) inhibitors, antineoplastic agents, proton pump inhibitors (PPIs), non-steroidal antiimflammatory drugs (NSAIDs), antidiabetic drugs, sulphonylureas, analgesics, and exogenous forms of $\mathrm{ADH}$ (vasopressin, desmopressin) [4].

Hyponatremia caused by the use of ADs usually occurs within 2 weeks of starting therapy [4], but sometimes it may take many months [5]. Risk factors for hyponatremia associated with administration of antidepressants include older age, female gender, somatic comorbid conditions and concomitant therapy. Early symptoms of hyponatremia are nausea, vomiting, anorexia, disorientation, headache, fatigue, weakness, and irritability, lethargy, confusion, and muscle cramps. Clinical severity of hyponatremia depends on the absolute level of serum sodium concentration as well as the abruptness of onset [6].

\section{CASE REPORT}

62 years old female patient, pensioner, living with husband, two children; right-handed. The patient had never been a smoker, nor consumed alcohol. She started first time psychiatric outpatient treatment four years ago, because of development of depressive episode of moderate severity. It was preceded by the illness and death of her grandchildren. The patient was receiving TCA maprotiline $2 \times 25 \mathrm{mg} /$ day and bromazepam $2 \times 3 \mathrm{mg}$ /day with regular check-ups with a local psychiatrist in the Health center. Due to cardiologist-diagnosed hypertension and Type 2a dyslipidemia she used enalapril $2 \times 10 \mathrm{mg} /$ day (optionally, with an increase in blood pressure $2 \times 20 \mathrm{mg} /$ day), metoprolol 2x50 mg/day, nifedipine $5 \mathrm{mg} /$ day, simvastatin $20 \mathrm{mg} /$ day, as well as diclofenac (on demand, with the pain) and bromazepam $3 \mathrm{mg} / \mathrm{day}$, on demand. She had no previous history of any endocrine diseases.

After a year of depression treatment with maprotiline and improving mood, there was a deterioration of general condition and appearance of confusion, unstable walking, cramps, along with an increase in blood pressure. At a local hospital was diagnosed hyponatremia (serum sodium concentration$112 \mathrm{mmol} / \mathrm{L}$ ). Except elevated blood level of cholesterol, the other biochemical and hematological parameters as well as thyroid hormones were within normal ranges. Serum osmolarity was $244 \mathrm{mOsm} / \mathrm{kg}$. Twenty-four hour urinary potassium was $75.3 \mathrm{mmol} / \mathrm{L}$ and $24 \mathrm{~h}$ urinary sodium was $74.7 \mathrm{mmol} / \mathrm{L}$. Computed tomography (CT) brain scan and radiological tests of other systems (X-ray of the heart and lungs and abdominal ultrasound) showed no pathological changes. Serum sodium level was normalized $(137 \mathrm{mmol} / \mathrm{L})$ by infusion of saline solution $0.9 \%$ and concentrated $10 \%$ saline solution and general condition of the patient improved. Except restriction of fluid intake, enalapril $2 \times 10 \mathrm{mg} /$ day, amlodipine $5 \mathrm{mg} /$ day and hydrochlorothiazide $12.5 \mathrm{mg}$ every 7 days were prescribed. After discharge from the Endocrinology Department, the patient con- 
tinued to take Maprotiline $2 \times 25 \mathrm{mg} /$ day and Bromazepam 3-6 mg/day, without consultation with her psychiatrist.

One year after the previous hospitalization, the patient was admitted to the Institute of Endocrinology of the tertiary level due to detailed re-examination, because of recurrent hyponatremia $(117 \mathrm{mmol} / \mathrm{l})$ which was corrected $(144 \mathrm{mmol} / \mathrm{l})$ with infusion therapy, conducted in Policlinic of a local hospital. Blood level of glucose, thyroid-stimulating hormone (TSH), free thyroxine (fT4), luteinizing hormone (LH), estradiol, prolactin were in the normal ranges.

Low dose adrenocorticotropic hormone (ACTH) test was normal, but the initial blood cortisol level was low as well as the base value of ACTH. Due to the low probability of hypocorticism, the Insulin Tolerance Test (ITT) [the gold standard for assessing the integrity of the hypothalamic-pituitary-adrenal (HPA) axis] was performed and its values were within normal limits (cortisol - 575.4 $\mathrm{mmol} / \mathrm{L}$, growth hormone $-6.7 \mathrm{mmol} / \mathrm{L}$ and prolactine $-485.2 \mathrm{mmol} / \mathrm{L}$ ). Serum osmolality was $296 \mathrm{mmol} / \mathrm{L}$ and urine osmolality was 215 $\mathrm{mmol} / \mathrm{L}$, during water restriction. Magnetic resonance imaging (MRI) of sellar region of pituitary gland showed no pathological changes.

Water test load (WTL) confirmed the Syndrome of inappropriate antidiuretic hormone secretion (SIADH).

Imaging tests showed no pathological pro- cesses that could be the cause of SIADH, and a multi-slice computed tomography (MCTH) of lungs was performed, which showed no pathological changes. Bisoprolol $5 \mathrm{mg} /$ day for hypertension was prescribed along with restriction of fluid intake as well as dietary regimen. She also used bromazepam $3 \mathrm{mg} /$ day and ginkgo biloba (prescribed from otologist for hearing disorder).

After discharge, the patient did not use antidepressants, was not heard from a psychiatrist and the mood was getting worse. She was shortly treated in Toxicology unit for taking bromazepam in excessive doses, "to treat insomnia". The patient started outpatient's psychiatric treatment at Psychiatric Department of tertiary level due to recurrent depressive episode of moderate severity, which was manifested by depressed mood, tearfulness, anxiety, lack of energy, occasional motor excitation, apathy, social restriction, and decrease in appetite, difficulty falling and staying asleep. The score of self-report The Beck Depression Inventory (BDI) [7] was 21.

The investigations that were conducted in the Institute for Endocrinology were excluded endocrine and other somatic causes of hyponatremia. Because her hyponatremia resolved after discontinuation of maprotiline therapy, maprotiline was thought to cause the patient's SIADH in this case. We administered The Adverse Drug Reaction (ADR) Probability Scale [8]. This scale was developed in 1991. by Naranjo and others in order to standardize
Table 1. The Naranjo Adverse Drug Reaction (ADR) Probability Scale score

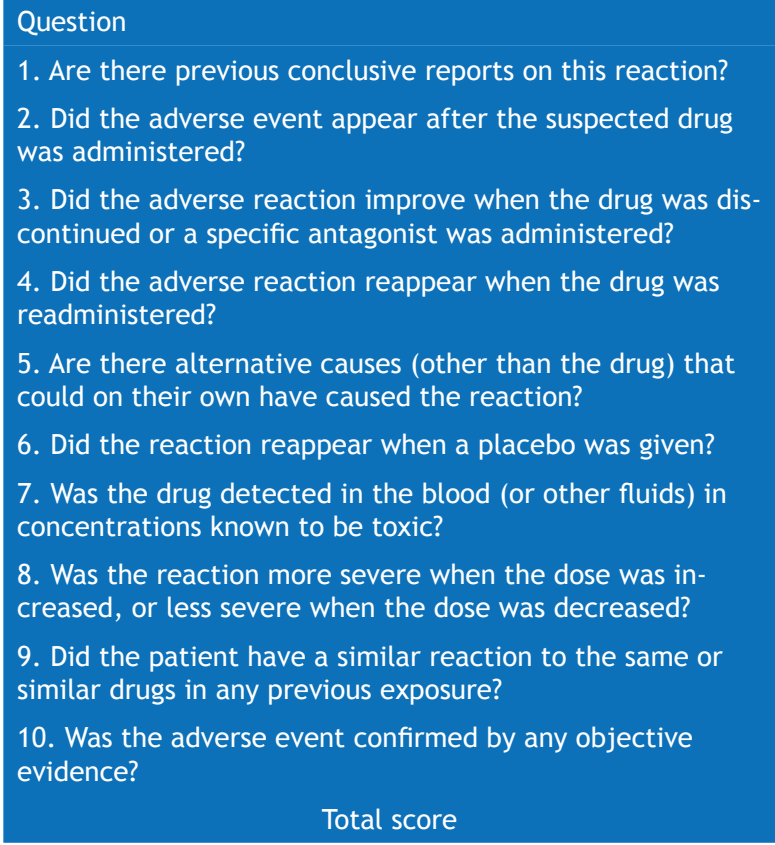

\begin{tabular}{|c|c|c|c|}
\hline Yes & No & Do Not Know & Score \\
\hline+1 & 0 & 0 & +1 \\
\hline+2 & -1 & 0 & +2 \\
\hline+1 & 0 & 0 & +1 \\
\hline+2 & -1 & 0 & +2 \\
\hline-1 & +2 & 0 & 0 \\
\hline-1 & +1 & 0 & 0 \\
\hline+1 & 0 & 0 & 0 \\
\hline+1 & 0 & 0 & 0 \\
\hline+1 & 0 & 0 & +1 \\
\hline+1 & 0 & 0 & +1 \\
\hline & & & +8 \\
\hline
\end{tabular}


the assessment of causality for adverse drug reactions. The ADR Probability Scale consists of 10 questions that are answered as Yes, No, or "Do not know". Total scores range from -4 to +13 . The score of 9 or higher considered that the reaction is definite, probable if 5 to 8 , possible if 1 to 4 , and doubtful if 0 or less. According to the criteria of the Naranjo Adverse Drug Reaction Probability Scale, the likelihood of maprotiline use causing hyponatremia in this case was "probable" (total score $=8$ ) (Table1.).

The novel antidepressant mirtazapine $(15 \mathrm{mg}$ at bad time and after 7 days, 30 $\mathrm{mg} /$ day), with a dual mode of action (alpha 2 antagonist; enhances the release of norepinephrine and 5-HT1A-mediated serotonergic transmission) (noradrenaline and specific serotonergic antidepressants) (NaSSA) was implemented because of its low risk of hyponatremia. Before administration of mirtazapine, serum sodium level was $137 \mathrm{mmol} / \mathrm{L}$. In addition to mirtazapine, the patient has used the first few months bromazepam. Based on selfreporting and family members reporting, the patients adhered to the prescribed pharmacological and non-pharmacological treatment.

After the administration of mirtazapine, in a patient there was a gradual reduction of depressive symptoms and the patient began to perform her daily activities. The BDI [7] score was 8 . The patient is regularly controlled by the cardiologist, blood pressure is normalized $(120 / 80 \mathrm{mmHg})$, and the current therapy is bisoprolol $2.5 \mathrm{mg} /$ day, enalapril $10 \mathrm{mg} /$ day (with an increase in blood pressure) and simvastatin $20 \mathrm{mg} /$ day. Blood sodium levels were within normal limits over the past 18 months (the most recent value-141 mmol/l).

Given that weight gain is one of the most common side effects of mirtazapine, we have followed this parameter in particular. Body mass index (BMI) was $26.5 \mathrm{~kg} / \mathrm{m} 2$ (body height $=1.55 \mathrm{~m}$, body weight $=65 \mathrm{~kg}$ ) before the initiation of mirtazapine treatment. Body weight of the patient wasn't considerably changed during the mirtazapine treatment.

\section{DISCUSSION}

A case report of hyponatremia due to maprotiline treatment in patient with a diagnosis of depressive episode has clinical significance, because hyponatremia is a common and potentially dangerous side effect of the use of psychotropic drugs $[2,9,10]$. The findings of previous studies have shown that the highest incidence of this metabolic disorders is in the use of serotonergic ADs [11,12]. However, a case description of our patient draws attention to the possibility of development of hyponatremia associated with other classes of ADs that are considered not to have a high risk of this side effect.

As we showed in our patient's report, hyponatremia may occur during the use of tricyclic antidepressant (TCA) maprotiline [which is sometimes classified as a tetracyclic antidepressant (TeTCA)] [13]. We conducted a detailed clinical, laboratory and other complementary tests $[14,15]$, after which we excluded endocrine and other somatic diseases as possible causes of hyponatremia in our patients. $\mathrm{AD}$ maprotiline proved to be probable cause of this electrolyte imbalance. After discontinuation of the maprotiline therapy, the serum sodium levels were within normal ranges (131$137 \mathrm{mmol} / \mathrm{L}$ ). According to the criteria of the Naranjo Adverse Drug Reaction Probability Scale, the likelihood of maprotiline use causing hyponatremia in this case was "probable" $($ score $=8)$. This category includes that the reaction

a) followed a reasonable temporal sequence after a drug,

b) followed a recognized response to the suspected drug,

c) was confirmed by withdrawal but not by exposure to the drug, and

d) could not be reasonably explained by the known characteristics of the patient's clinical state [8].

The association between the use of $\mathrm{ADs}$ and the changes of serum sodium concentration was first described precisely during the application of TCA - amitriptyline, 1974 [16]. And other research findings [17] suggested a considerable association between TCA and the occurrence of hyponatremia. The results of some recent studies [18] showed a lower incidence of hyponatremia in the application of TCAs $(0.01 \%-0.33 \%)$ in comparison with previous studies $(16.7 \%)[19,20]$, that can be explained by different methodological approaches (active monitoring, higher hyponatremia threshold).

The pathogenesis of hyponatremia in the use of TCAs is not clearly understood. The patient who was represented, diagnosed with the Syndrome of inappropriate antidiuretic hormone secretion (SIADH) [14,15], after en- 
docrine examination. This syndrome is usually considered as a cause of hyponatremia induced by ADs. Thus, Mannesse et al. [21] were observed in $50 \%$ of the sample recorded SIADH, and with $25 \%$ of "possible SIADH". In patients with SIADH, more than half were "most likely" caused by the use of $\mathrm{AD}$, in a third "possible", while in one patient "suspected".

Certain studies have shown that serotonergic mechanisms are involved in regulating the secretion of $\mathrm{ADH}[22,23]$, while other studies did not confirm it [24]. The animal studies have shown that both neurotransmitters, noraderenalin (NA) and serotonin (5-hydroxy tryptamine) (5-HT) may increase the secretion of ADH by stimulatiing alphaadrenergic and serotonergic receptors [25]. Namely, in the study of Klein [26] has been shown that NA increases the excretion of sodium. It is known that both neurotransmiterrs, NA and 5-HT are involved in the control of secretion of arginine - vasopressin (AVP) [27]. Koelkebeck et al. [28] have pointed to the role of the NA in the development of hyponatremia in a case report of hyponatremia induced by reboxetine (noradrenergic reuptake inhibitor) (NRI). These findings may help in considering the mechanisms of hyponatremia with the administration of the drug, which is used by our patients, maprotiline, bearing in mind its pharmacological profile (enhances the NA level in the synaptic cleft, through the strong inhibition of its reuptake in the level of presynaptic neuron). Further research is necessary to elucidate the neurobiological mechanisms of occurrence of this undesired effect of AD therapy.

Hyponatremia in our patient was diagnosed after 12 months of the maprotiline treatment. According to several studies, TCA have attenuated risk profile for the development of hyponatremia in relation to other classes of ADs. So, later diagnosis of hyponatremia may be associated with a modest reduction in serum sodium level. Early symptoms of this disorder (fatigue, lethargy, weight loss) are nonspecific and can mimic the symptoms of psychiatric disorders. According to the literature, the time of occurrence of hyponatremia caused by the use of ADs varies greatly, and the results of the study has shown that this side effect of the drug may occur from one day to several months after starting therapy [29]. This information is important to bear in mind because of the necessity to increase awareness of physicians for this complication of AD therapy, and because of the possibility of its misdiagnosis. It is therefore recommended routine analyzed the serum sodium concentration in the first 2 weeks of therapy in patients with risk factors for development of this electrolytic disturbance as well as in those with lower serum sodium level at the beginning of the treatment. This is important, because the delayed recognition and treatment of hyponatremia can lead to irreversible neurological damage and death [30].

In our patient, there were several risk factors for the occurrence of this electrolyte disturbance: older age (60 yrs.), female sex and the use of concomitant antihypertensive therapy (ACE inhibitor enalapril) [4].

The results of numerous studies have shown that older patients ( $\geq 65$ years) had more than six fold increased risk for hyponatraemia than younger patients [2]. Bowman et al. [20] indicated that in approximately $25 \%$ of elderly patients on the treatment of ADs have occurred hyponatremia. According to Mannesse et al. [21], in the majority of patients older than 60 years, hyponatremia was caused by the use of TCAs (11.5\%), followed by SSRIs (10.2\%), venlafaxine (SNRIs) (8.6\%) and mirtazapine (NaSSA) (5.6\%). The reduction in renal blood flow, glomerular filtration rate and renal tubular damage concentration makes the elderly prone to the occurrence of hyponatremia. Aging also leads to changes in water balance due to changes in stimulating the release of vasopressin and changes in renal response to vasopressin [21]. These data are important because SSRIs are often used in the elderly because they have a more favorable adverse effects profile in relation to TCAs. However, there are studies which show that the occurrence of hyponatremia is not associated with age [21].

Another drug that the patient used to control hypertension, enalapril (in cotherapy with other antihypertensive agents), that, according to data from the literature, carries a risk for hyponatremia has continued to use even after maprotiline off, but there was no electrolyte imbalance. The results of Kirby et al. study [31] also showed that concomitant use of non-psychotropic drugs, such as ACE inhibitor in the treatment of arterial hypertension increases the risk of hyponatremia. Hypertension (and other somatic diseases, common in the elderly) [32] may impair the 
severity of hyponatremia or mask its beginning [33].

Most studies show that women have greater risk for developing hyponatremia induced by AD therapy. Sex differences in occurrence of hyponatremia caused by $\mathrm{AD}$ were primarily associated with hormonal activity. Thus, estrogen (but not progesterone) stimulates the secretion of AVP [34], and women may have a higher sensitivity on ADH with an increase in the expression of vasopressin renal receptors [35]. However, there are studies, whose results have not shown the influence of sex on the incidence of hyponatremia with the use of $\mathrm{AD}$ therapy $[2,21]$.

To continue treatment with mirtazapine [36], we decided because of demonstrated lower incidence of hyponatremia during administration of this drug [24]. The research findings suggested that mirtazapine may be an alternative in the treatment of patients with increased risk of hyponatremia. Thus, the German multicenter drug surveillance program AMSP in psychiatric patients has not found a single case of the occurrence of hyponatremia induced by mirtazapine on a sample of 28172 patients [37]. The findings of retrospective study by Jung et al. [38] showed that none of the 76 patients on mirtazapine have developed hyponatremia compared to $8 \%$ of patients on SSRIs and $4 \%$ of patients on venlafaxine. During the implementation of mirtazapine, in our patient there was an improvement in mood and reduction of anxiety, irritability, and insomnia.

We continue to implement restrictions on fluid intake, dietary diet and regular check-ups with an endocrinologist and a cardiologist with regular monitoring of serum sodium, and other hematological and biochemical parameters.

\section{CONCLUSION}

Considering these facts, it can be concluded that in patients with different risk factors for developing hyponatremia, should determine serum sodium concentration, before and during the application of antidepressant therapy, because many patients may have undiscovered hyponatremia, which can be exacerbated by prescribing antidepressant.

In patients with the appearance of hyponatremia, it is necessary to carry out a detailed endocrine examination, in order to exclude other, somatic causes of this electrolyte disturbance. The restriction of fluid intake, along with discontinuation of antidepressant is the first strategies in the treatment. Better awareness and knowledge of risk factors associated with other classes of antidepressants for the development of hyponatremia can help clinicians in the choice of the drug, thus allowing safe treatment for patients at risk, particularly patients with a history of SIADH or those who are showing the first signs of hyponatremia during the current application of AD.

\section{REFERENCES}

1. Palmer BF, Gates JR, Lader M. Causes and management of hyponatremia. Ann Pharmacother. 2003; 37: 1694-702.

2. Movig KL, Leufkens HG, Lenderink AW, van den Akker VG, Hodiamont PP, Goldschmidt HM, Egberts AC. Association between antidepressant drug use and hyponatraemia: a case-control study. $\mathrm{Br} \mathrm{J}$ Clin Pharmacol. 2002; 53(4): 363-9.

3. Bogunovic OJ, Sotelo J, Madhusoodanan S. Hyponatremia secondary to antidepressants. Psychiatric Annals. 2003; 33: 333-9.

4. Liamis $G$, Milionis $H$, Elisaf M. A Review of DrugInduced Hyponatremia. Am J Kidney Dis. 2008; 52:144-53.

5. Arinzon ZH, Lehman YA Fidelman ZG, Krasnyansky II. Delayed recurrent SIADH associated with SSRls. Annals of Pharmacotherapy. 2002; 36: 1175- 7.

6. Adrogué HJ. Consequences of Inadequate Management of Hyponatremia. American Journal of Nephrology. 2005; 25(3): 240-9.

7. Beck AT, Ward CH, Mendelson M, Mock J, Erbaugh J. An inventory for measuring depression. Arch Gen Psychiatry. 1961; 4: 561-71.

8. Naranjo CA, Busto U, Sellers EM, Sandor P, Ruiz I, Roberts EA, Janecek E, Domecq C, Greenblatt DJ. A method for estimating the probability of adverse drug reactions. Clin Pharacol Ther. 1981;30: 23945 .

9. Kirby D, Ames D. Hyponatraemia and selective serotonin re-uptake inhibitorsin elderly patients. Int J Geriatr Psychiatry. 2001; 16(5):484-93.

10. Fabian TJ, Amico JA, Kroboth PD, Mulsant BH, Corey SE, Begley AE, Bensasi SG, Weber E, Dew MA, Reynolds CF 3rd, Pollock BG. Paroxetine-induced hyponatremia in older adults: a 12-week prospective study. Arch Intern Med. 2004; 16(3):327-32.

11. Liu BA, Mittmann N, Knowles SR, Shear NH. Hyponatremia and the syndrome of inappropriate secretion of antidiuretic hormone associated with 
the use of selective serotonin reuptake inhibitors: a review of spontaneous reports. Can Med Assoc J. 1996; 155: 519-27.

12. Ball CJ, Herzberg J. Hyponatremia and selective serotonin reuptake inhibitors. Int J Geriatr Psychiatry. 1994; 9:819-22.

13. Stahl SM. Maprotiline. In: Sthal SM, editor. Essential psychopharmacology: the prescribers guide: antidepressants. Fourth edition. Cambridge University Press; 2011. p. 129-34.

14. Spasovski G, Vanholder R, Allolio B, Annane D, Ball S, Bichet D, Decaux G, Fenske W, Hoorn EJ, Ichai C, Joannidis M, Soupart A, Zietse R, Haller M, van der Veer S, Van Biesen W, Nagler E; Hyponatraemia Guideline Development Group. Clinical practice guideline on diagnosis and treatment of hyponatraemia. Eur J Endocrinol. 2014; 170(3): G1-47.

15. Sherlock M, Thompson CJ. The syndrome of inappropriate antidiuretic hormone: current and future management options. Eur J Endocrinol. 2010; 162 (Suppl. 1): S13-8.

16. Luzecky MH. The syndrome of inappropriate antidiuretic hormone secretion associated with amitriptyline administration. South Med J. 1974;67: 495-7.

17. Siegler EL, Tamres D, Berlin JA, Allen-Taylor L, Strom BL. Risk factors for the development of hyponatremia in psychiatric patients. Arch Intern Med. 1995; 155: 953-7.

18. Letmaier M, Painold A, Holl AK, Vergin H, Engel R, Konstantinidis A, Kasper S, Grohmann R. Hyponatremia during psychopharmacological treatment: results of a drug surveillance programme. Int J Neuropsy-chopharmacol. 2012; 15(6):739-48.

19. Spigset O, Hedenmalm K. Hyponatraemia and the syndrome of inappropriate antidiuretic hormone secretion (SIADH) induced by psychotropic drugs. Drug Saf. 1995; 12(3): 209-25.

20. Bouman WP, Pinner G, Johnson H. Incidence of selective serotonin reuptake inhibitor (SSRI) induced hyponatraemia due to the syndrome of inappropriate antidiuretic hormone (SIADH) secretion in the elderly. Int J Geriatr Psychiatry. 1998;13:12-5.

21. Mannesse CK, Jansen PA, Van Marum RJ, Sival RC, Kok RM, Haffmans PM, Egberts TC. Characteristics, prevalence, risk factors, and underlying mechanism of hyponatremia in elderly patients treated with antidepressants: A cross-sectional study. Maturitas. 2013; 76(4): 357-63.

22. Anderson IK, Martin GR, Ramage AG. Central administration of 5-HT activates $5-\mathrm{HT} 1 \mathrm{~A}$ receptors to cause sympathoexcitation and $5-\mathrm{HT} 2 / 5-\mathrm{HT} 1 \mathrm{C}$ receptors to release vasopressin in anaesthetized rats. Br J Pharmacol. 1992;107:1020-8.

23. Brownfield MS, Greathouse J, Lorens SA, Armstrong J, Urban JH, Van de Kar LD. Neuropharmacological characterization of serotoninergic stimu- lation of vasopressin secretion in conscious rats. Neuroendocrinology. 1988; 47(4): 277-83.

24. Marar IE, Amico JA. Vasopressin, oxytocin, corticotrophin-releasing factor, and sodium responses during fluoxetine administration in the rat. Endocrine. 1998;8:13-8.

25. De Picker L, Van Den Eede F, Dumont G, Moorkens G, Sabbe BG. Antidepressants and the Risk of Hyponatremia: A Class-by-Class Review of Literature. Psychosomatics. 2014; 55(6): 536-47.

26. Klein LA. Alpha-Adrenergic (norepinephrine) effect on antidiuretic hormone activity. Invest Urol. 1975; 13(2):159-64.

27. Vacher $C M$, Frétier $P$, Créminon $C$, Calas $A$, Hardin-Pouzet H. Activation by Serotonin and Noradrenaline of Vasopressin and Oxytocin Expression in the Mouse Paraventricular and Supraoptic Nuclei. J Neuroscienci. 2002; 22(5):1513-22.

28. Koelkebeck K, Domschke K, Zwanzger P, Hetzel G, Lang D, Arolt V. A case of non-SIADH-induced hyponatremia in depression after treatment with reboxetine. The World Journal of Biological Psychiatry. 2009; 10(4 Pt 2): 609-11.

29. Kirchner V, Silver LE, Kelly CA. Selective serotonin reuptake inhibitors and hyponatraemia: review and proposed mechanisms in the elderly. $J$ Psychopharmacol. 1998; 12: 96-400.

30. Soiza RL, Talbot HSC. Management of hyponatremia in older people: old threats and new opportunities. Ther Adv Drug Saf. 2011; 2(1): 9-17.

31. Kirby D, Harrigan S, Ames D. Hyponatraemia in elderly psychiatric patients treated with selective serotonin reuptake inhibitors and venlafaxine: a retrospective controlled study in an inpatient unit. Int J Geriatr Psychiatry. 2002; 17(3): 231-7.

32. Madhusoodanan S, Bogunovic OJ, Moise D, Brenner R, Markowitz S, Sotelo J. Hyponatremia associated with psychotropic medications. A review of the literature and spontaneous reports. Adverse Drug React Toxicol Rev. 2002; 21:17-29.

33. Clemens JP. "Hyponatremia in Elderly Patients Treated for Depression With Selective Serotonin Reuptake Inhibitors Versus Tricyclic Antidepressants" (2012). School of Physician Assistant Studies. Paper 299.

34. Forsling ML, Stromberg P, Akerlund M. Effect of ovarian steroids on vasopressin secretion. J Endocrinol. 1982; 95:147-51.

35. Juul KV, Klein BM, Sandström R, Erichsen L, Nørgaard JP. Gender difference in antidiuretic response to desmopressin. Am J Physiol Renal Physiol. 2011; 300(5): F1116-F1122.

36. Anttila SAK, Leinonen EVJ. A review of the pharmacological and clinical profile of mirtazapine. CNS Drug Rev. 2001; 7(3): 249-64. 
37. Degner D, Grohmann R, Kropp S, Rüther E, Bender S, Engel RR, Schmidt LG. Severe adverse drug reactions of antidepressants: results of the German multicenter drug surveillance program AMSP. Pharmacopsychiatry. 2004;37: 39-45.

38. Jung Y-E, Jun T-Y, Kim K-S, Bahk W-M. Hyponatremia associated with selective serotonin reuptake inhibitors, mirtazapine and venlafaxine, in Korean patients with major depressive disorder. Int J Clin Pharmacol Ther. 2011; 29(7): 437-43. 


\title{
Prikaz slučaja hiponatremije povezane sa lečenjem maprotilinom
}

\author{
Žana B. Stanković ${ }^{1}$,Zorana Z. Pavlović ${ }^{1,3}$, Milica J. Jovičić ${ }^{1}$, Miloš P. Žarkovićc,3 \\ ${ }^{1}$ Klinika za psihijatriju, Klinički Centar Srbije, Beograd, Srbija \\ ${ }^{2}$ Institut za endokrinologiju, dijabetes i bolesti metabolizma, Klinički Centar Srbije, Beograd, Srbija \\ ${ }^{3}$ Medicinski fakultet, Univerzitet u Beogradu, Beograd, Srbija
}

\section{KRATAK SADRŽAJ}

Uvod: Maprotilin je triciklični antidepresiv (ponekad klasifikovan kao tetraciklični antidepresiv), koji je pretežno inhibitor ponovnog vraćanja norepinefrina/noradrenalina, obično propisivan za depresiju.

Cilj: Prikazati pacijentkinju sa depresivnom epizodom i pojavom hiponatremije tokom lečenja maprotilinom.

Prikaz slučaja: Kod 62-godišnja žene je dijagnostikovana depresivna epizoda pre četiri godine. Ona je lečena ambulantno maprotilinom, $50 \mathrm{mg} /$ dnevno i bromazepamom 6 $\mathrm{mg} /$ dnevno, kod nadležnog psihijatra. Pacijentkinja je takođe koristila enalapril $2 \times 10$ $\mathrm{mg} /$ dnevno, metoprolol $2 \times 50 \mathrm{mg} /$ dnevno, nifedipin $5 \mathrm{mg} /$ dnevno i simvastatin $20 \mathrm{mg} /$ dnevno za lečenje hipertenzije i dislipidemije. Nakon oko 12 meseci upotrebe maprotilina, bila je hospitalizovana na Endokrinološkom odeljenju lokalne bolnice zbog pojave konfuzije, nestabilnog hoda, grčeva, kao i povećanja krvnog pritiska. Tada je dijagnostikovana hiponatremija (nivo natrijuma u serumu -112 mmol/L), korigovana (137 mmol/L) upotrebom parenteralne terapije. Pacijentkinja je nastavila da koristi maprotilin bez konsultacije sa svojim psihijatrom. Nakon godinu dana, pacijentkinja je (ponovo) hospitalizovana na Endokrinološkom odeljenju tercijarnog nivoa radi detaljnog ispitivanja zbog rekurentne hiponatramije $(117 \mathrm{mmol} / \mathrm{L})$, korigovane (136 $\mathrm{mmol} / \mathrm{L}$ ) ambulantnom primenom parenteralne terapije u lokalnoj bolnici. Primenjen je Test opterećenja vodom i postavljena dijagnoza Sindroma neadekvatnog lučenja antidiuretskog hormona. Test tolerancije na insulin je pokazao očuvan integritet osovine hipotalamus-hipofiza-nadbubreg. Antidepresiv mirtazapin (15 mg/dnevno) je uveden zbog ponovne pojave depresije. Tokom tretmana mirtazapinom je opservirano postepeno smanjenje depresivnih simptoma. Antihipertenzivna terapija, ograničenje unosa tečnosti i dijetetski režim se $i$ dalje primenjuju. Koncentracije natrijuma u serumu su bile u normalnim granicama proteklih 18 meseci.

Zaključak: Nivo natrijuma u serumu treba meriti pre i tokom terapije bilo kojom klasom antidepresiva, posebno kod onih pacijenata sa povećanim rizikom od pojave hiponatremije.

Ključne reči: antidepresivi, neželjeni efekti, hiponatremija, maprotilin, mirtazapin 